\title{
Do Good Corporate Governance and Profitability Affect Companies on Submitting the Annual Financial Report on Time?
}

\author{
Rizka Meilisa ${ }^{1}$, Dwi Indah Lestari ${ }^{2}$ \\ \{rizkaameilisa@gmail.com ${ }^{1}$, dwi.lestari@unjani.ac.id ${ }^{2}$ \} \\ Economy and Business Faculty, Jenderal Achmad Yani University, Indonesia ${ }^{1}$, Economy and \\ Business Faculty, Jenderal Achmad Yani University, Indonesia ${ }^{2}$
}

\begin{abstract}
This study aimed to determine the effect of Good Corporate Governance, which were audit committee, independent commissioner, managerial ownership, institutional ownership, and profitability on the financial report submission's timeliness in mining sector companies listed on the Indonesia Stock Exchange for the year 2014 to 2018. We were using purposive sampling technique and obtained 190 samples from 38 companies. The samples were then tested using logistic regression analysis technique. The result showed that the partial audit committee and profitability have a positive impact on financial statement submission's timeliness, meanwhile, independent commissioner, managerial ownership, and institutional ownership do not affect the timeliness of financial statement submission.
\end{abstract}

Keywords: Good Corporate Governance, audit committee, independent commissioner, managerial ownership, institutional ownership, and profitability, financial statement submission's timeliness).

\section{Introduction}

In order to obtain additional capital and enhance their value, many companies decide to be listed in the Indonesia Stock Exchange and change their state to go public company. One of some requirements to be a listed company is that the company must be submitting the company's annual financial statement and annual report which are made based on Indonesia Financial Accounting Standard. The submitted financial statement must be audited by Bapepam's public accountant. Company's annual report provides information about the entity's achievement in a year. From the annual report, the users could find information about the company's performance and annual financial statement.

The annual financial statement and annual report that were submitted to Indonesia Stock Exchange would be the information source used by shareholders, investors, and/or prospective investors as the base of decision-making. Annual financial statements and annual reports must be submitted according to the determined due date, thus the information given are credible. The Board of Directors of the Jakarta Stock Exchange Regulation No. I-E Number Kep306/BEJ/07-2004 about the informational obligation state that audited annual financial statements must be submitted at least at the end of the third month after the reported date. Meanwhile, based on Financial Services Authority Regulation Number 29/POJK.04/2016 
concerning Annual Report of Issuer or Public Company article 7(1) declare that the entity's annual report must be submitted at least at the end of the fourth month after the reported date.

These regulations were made along with the penalties. These penalties are written in The Board of Directors of Jakarta Stock Exchange Number Kep-307/BEJ/07-2004 and Financial Services Authority Regulation Number 29/POJK.04/2016 Chapter 6 article 19. Despite there being regulations and penalties, still, plenty of companies could not submit their financial statements on time. According to Exchange Announcement Number Peng-LK00001/BEI.PP1.PP2.PP3/01-2020, ten companies have not presented their third quarter's financial statements ended September 30th 2019.

In those announcement, two out of ten of the companies are mining's sector companies, which are Borneo Lumbung Energi \& Metal Inc. (BORN) and Cakra Mineral Inc. (CKRA). Both companies are charged with an SP3's penalty and a fine of Rp150,000,000. The Indonesia Stock Exchange extended the suspension of Cakra Mineral Inc. (CKRA) up to February 20th 2020, while Borneo Lumbung Energi \& Metal Inc. (BORN) declared delisting from Indonesia Stock Exchange with cause of force delisting. Aside from those two companies, here are some mining companies which can not submit their annual financial statements on time.

Table 1. Mining Companies which are Late on Submitting Annual Financial Report for the year 2018

\begin{tabular}{clcc}
\hline No. & \multicolumn{1}{c}{ Company's Name } & $\begin{array}{c}\text { Submission } \\
\text { Date }\end{array}$ & Lateness \\
\hline 1. & $\begin{array}{l}\text { Astrindo Nusantara Infrastruktur } \\
\text { Inc. (BIPI) }\end{array}$ & $19 / 04 / 02$ & 2 days \\
2. & $\begin{array}{l}\text { Energy Mega Persada Inc. (ENRG) } \\
\text { 3. }\end{array} \quad \begin{array}{ll}\text { Medco Energi Internasional Inc. } \\
\text { (MEDC) }\end{array}$ & $19 / 06 / 03$ & 64 days \\
4. & Surya Esa Perkasa Inc. (ESSA) & $19 / 04 / 03$ & 3 days \\
\hline
\end{tabular}

This phenomenon shows that a lot of go public companies presented their financial report inconsistent to the due date, likewise some companies from the mining sector. Some researches have been done to find out what are the factors that affect financial statements submission timeliness. The timeliness of financial statements submission is closely related to the concept of Good Corporate Governance (GCG) because one of GCG's principles is timeliness [1]. The Good Corporate Governance help manage and control the company in order to create added value for every stakeholders, emphasizing the importance of shareholders' rights to acquire the relevant, accurate, and punctual information, also emphasizing the importance of company's responsibility to disclose the information about the company's performance, ownership, and stakeholder accurately, punctually, and transparently [1]. The mechanisms of Good Corporate Governance marked by institutional ownership, managerial ownership, independent commissioner, and audit committee [2].

Another aspect that can affect the financial statement's timeliness is the company's profitability. If a company has a low rate of profitability, that means that the information provided by the company contains negative signals. If it is the case, the company tends to 
present their financial statement way later than the companies that have high rate profitability $[3]$.

There are some more factors that probably affect a company's financial statement's timeliness, such as company size and solvability [4]. But the focus of this research are the mechanisms of Good Corporate Governance and profitability because those variables are reflected in the phenomenon in the mining industry in the observed period.

\section{Literature Review}

\subsection{Compliance Theory}

Compliance theory urges the companies to submit their financial statements on time because it is their responsibility to do so and companies assume that submitting the report on time will be beneficial for the users [5]. According to [6], compliance theory categorized organizations' power into three types of power which are coercive, remunerative, and normative. Coercive power will threaten the lower level participants and this kind of power use to be applied in the jail or military organizations. Remunerative power will control the participant by giving them extrinsic reward such as wages, commission, and so on [7]. On the other hand, normative power controls the participant by giving them intrinsic rewards such as new challenges, attention from the higher level party, and positive attitude [7]

\subsection{Good Corporate Governance and Timeliness of Financial Statements' Submission}

There are four mechanisms of Good Corporate Governance such as audit committee, independent commissioner, managerial ownership, and institutional ownership. The main role of the audit committee is to improve the quality of the financial statements, enhance public trust, and decrease the possibility of reporting the financial statements late [8]. In Indonesia, the audit committee must be led by an independent commissioner [9]. Independent commissioners should not have any relation to the major shareholders, board of directors, and the commissioner [10]. The role of independent commissioners is to provide an objective and positive measurement to the management as the basis of decision making [11]. Managerial ownership is the percentage of shares owned by manager, director, and commissioner who are actively taking part in decision making [12]. Managers will build more sense of responsibility to run the company way better in order to achieve the company's objective since they own the company's share [13]. The percentage of shares owned by institution investors, such as insurance companies or banks, named as institutional ownership [14]. This ownership is assumed to be an effective control to the manager's decisions because the institution investors will supervise the activities of the company so that they can meet their needs [10], [11]. If the companies have all the mechanisms and run their job description well, it said that the companies will be able to report their financial statements on time.

\subsection{Profitability and Timeliness of Financial Statements' Submission}

Profitability defined as the measurement of companies' objective. It shows how the companies utilize their resources to gain the profit [15]. The ratio that measure profitability is Return on Assets (ROA) by divide the earn after tax to the total assets [16]. The higher percentage of ROA means that the companies been able to utilize their assets and gain profit. In that case, companies tend to report their financial statements on time [3]. 


\section{Research Method}

This research is a quantitative research and uses logistic regression as the analysis technique. The population chosen in this research is the mining sector companies that are listed in Indonesia Stock Exchange for the year 2014-2018. The samples selected by a purposive sampling method with these criterias: the mining companies listed in Indonesia Stock Exchange for the year 2014-2018 and published the completed annual financial statements. Based on the criteria obtained 190 samples from 38 companies.

The independent variables in this research are audit committee $\left(\mathrm{X}_{1}\right)$ that indicated by the amount of audit committee member in the company, independent commissioner $\left(\mathrm{X}_{2}\right)$ that indicated by the amount of independent commissioner in the company, managerial ownership $\left(\mathrm{X}_{3}\right)$ that indicated by the percentage of shares owns by the manager in the company, institutional ownership $\left(\mathrm{X}_{4}\right)$ that indicate by the percentage of shares owns by the institution investors, and profitability $\left(\mathrm{X}_{5}\right)$ that indicate by the percentage of Return on Assets. The dependent variable in this research is the timeliness of the annual financial statement's submission. The valuation of this variable uses a dummy variable that categorizes the timeliness into 1 and 0 . The companies that submitted the financial statements on time represented by 1 and the companies that were late on submitted the financial statements represented by 0 .

The hypothesis testing done by formulated the hypothesis $0\left(\mathrm{H}_{0}\right)$ as the hypothesis which states that the independent variables do not affect the dependent variable and alternative hypothesis $\left(\mathrm{H}_{\mathrm{a}}\right)$ as the hypothesis which states that the independent variables affect dependent variables positively.

\section{Result and Discussion}

The first test done was Overall Model Fit to find out if there was reduction to the value of -2 Log Likelihood (-2LL) from block number=0 to block number=1.

Table 2. Overall Model Fit Block 1: Method = Enter

\begin{tabular}{rrrrrrrrr}
\hline \multicolumn{2}{c}{ Iteration } & \multicolumn{2}{c}{ Log } & \multicolumn{5}{c}{ Coefficients } \\
& & Likelihood & Constant & \multicolumn{1}{c}{ KA } & KOIN & MANJ & INST & ROA \\
\hline Step 0 & 1 & 208.474 & -.651 & .444 & .129 & .006 & -.384 & 4.294 \\
& 2 & 205.217 & -1.169 & .606 & .160 & .707 & -.351 & 6.281 \\
& 205.050 & -1.336 & .651 & .158 & .939 & -.305 & 6.908 \\
& 205.050 & -1.346 & -.653 & .158 & .952 & -.301 & 6.952 \\
4 & 205.050 & -1.346 & -.653 & .158 & .952 & -.301 & 6.952 \\
\hline
\end{tabular}

The hypothesis of overall model have fitted the data. The independent variables, which are audit committee (KA), independent commissioner (KOIN), managerial ownership (MANJ), institutional ownership (INST), and profitability (ROA), proved to have the ability to fix the fit model and be able to show a better regression model. 
Table 3. Nagelkerke R Square

\begin{tabular}{ccccc}
\hline Step & $\begin{array}{c}\mathbf{- 2} \text { Log } \\
\text { Likelihood }\end{array}$ & $\begin{array}{c}\text { Cox \& Snell R } \\
\text { Square }\end{array}$ & $\begin{array}{c}\text { Nagelkerke R } \\
\text { Square }\end{array}$ \\
\hline 1 & $205.050_{\mathrm{a}}$ & .140 & .198 \\
\hline
\end{tabular}

Determination coefficient test was done to find out how much the independent variables were able to describe the dependent variable. Based on Table 3, the value of Nagelkerke $\mathrm{R}$ Square 0.198 shows that independent variables in this research only have $19.80 \%$ ability to describe the variation of dependent variables. The rest $80.20 \%$ could be described by another independent variables outside this research

Table 4. Hosmer and Lemeshow Test

\begin{tabular}{rrrr}
\hline \multicolumn{1}{c}{ Step } & Chi-Square & df & Sig. \\
\hline 1 & 7.128 & 8 & .523 \\
\hline
\end{tabular}

The Hosmer and Lemeshow Test was done to know if the data fitted the model or not. Table 4 shows the value 7.128 of chi-square and Sig. 0.523. It means that the logistic regression model have been fitted and there is no significant difference with the observation value. It could be said that the data deserve to be used for further analysis.

Table 5. Regression Coefficient Test (Wald Test)

\begin{tabular}{|c|c|c|c|c|c|c|c|c|c|}
\hline & & \multirow[t]{2}{*}{ B } & \multirow[t]{2}{*}{ S.E. } & \multirow[t]{2}{*}{ Wald } & \multirow[t]{2}{*}{ df } & \multirow[t]{2}{*}{ Sig. } & \multirow[t]{2}{*}{$\operatorname{Exp}(B)$} & \multicolumn{2}{|c|}{$\begin{array}{c}95 \% \text { C.I. For } \\
\text { EXP(B) }\end{array}$} \\
\hline & & & & & & & & $\begin{array}{c}\text { Low } \\
\text { er }\end{array}$ & Upper \\
\hline \multirow[t]{6}{*}{ Step 1a } & KA & .653 & .315 & 4.314 & 1 & .038 & 1.922 & 1.037 & 3.561 \\
\hline & KOIN & .158 & .236 & .445 & 1 & .505 & 1.171 & .737 & 1.860 \\
\hline & MANJ & .952 & 1.397 & .447 & 1 & .490 & 2.592 & .174 & 38.681 \\
\hline & INST & -.301 & .884 & .116 & 1 & .733 & .740 & .131 & 4.188 \\
\hline & ROA & 6.952 & 1.951 & 12.698 & 1 & .000 & 1045.352 & 22.833 & 47875.747 \\
\hline & Constant & -1.346 & 1.215 & 1.227 & 1 & .268 & .260 & & \\
\hline
\end{tabular}

Regression coefficient test was done to know the relation between each independent variable and the dependent variable. According to the table above, here is the formulated logistic regression model:

$\overline{\operatorname{Ln} \overline{1-K W P L R}}=-1.346+0.653 \mathrm{KA}+0.158 \mathrm{KOIN}+0.952 \mathrm{MANJ}-0.301 \mathrm{INST}+6.952 \mathrm{ROA}+\epsilon$

Based on Table 5 the significant value for the audit committee is 0.038 which means the probability rate of the audit committee is lower than 0.05 . This means that $\mathrm{H}_{01}$ rejected and 
$\mathrm{H}_{\mathrm{a} 1}$ accepted. It concludes that the audit committee positively and significantly affects the timeliness of annual financial statement's submission. The industry average for the audit committee's quantity in a company is 3 (three) people. If a company has at least three members of committee audit, it could be said that it helps the company to improve the company performance. This result supports the study conducted by [2], [17], and [18]. The Audit committee helps the auditor to hasten the process of financial statement auditing.

The significant value of independent commissioner is $0.505>0.05$ equals to the rejection of $\mathrm{H}_{\mathrm{a} 2}$ and acceptance of $\mathrm{H}_{02}$. Thus, an independent commissioner has no effect on the financial statement's timeliness. This result supports previous research conducted by [18]. Even though the company has applied the principles of corporate governance, the amount of independent commissioner has nothing to do to help quicken the delivery of company's financial statements [18].

The significant value of managerial ownership is 0.491 , higher than 0.05 which means that $\mathrm{H}_{03}$ accepted and $\mathrm{H}_{\mathrm{a} 3}$ rejected. It said that managerial ownership has no effect on the financial statement's timeliness. This result supports the research conducted by [17] and [13] which said that the existence of managerial ownership could not guarantee the financial statement be reported on time. However, this is not in accordance with the research conducted by [1] which said that the manager of the company will continue to improve the companies' performance in order to gain the higher profit, so that the financial statement will be able to be reported faster.

The significant value of institutional ownership is $0.733>0.05$. This means that $\mathrm{H}_{04}$ accepted and $\mathrm{H}_{24}$ rejected. It concluded that institutional ownership has no effect on the timeliness of financial statements. Even though a lot of the companies have a high percentage of institutional ownership, not all of those companies were able to report their financial statement on time, while some companies with lower percentages were able to report their financial statement to the due date. This is in accordance to the research conducted by [1] but the result is opposing the result by [2] and [19] which said that institutional ownership has effect to the timeliness of financial statements' submission.

The significant value of profitability is 0.000 obviously lower than 0.05 that means $\mathrm{H}_{\mathrm{as}}$ accepted and $\mathrm{H}_{05}$ rejected. This concluded that profitability positively and significantly affected the timeliness of financial statement's submission. The industrial average of profitability in this research is $2.36 \%$. This can be interpreted that the majority of the mining companies successfully attained profit and maintained to report their financial statements on time. This is in accordance with the study conducted by [20] and [21]. Their research said that profitability shows that the company has succeeded to obtain profits which send the good signal to the stakeholders and the shareholders.

\section{Conclusion}

It can be concluded that audit committee and profitability positively and significantly affect the timeliness of annual financial statement's submission, meanwhile independent commissioner, managerial ownership, and institutional ownership has no effect on the timeliness of financial statement's submission. 


\section{References}

[1] R. Amelia, "Pengaruh Mekanisme Corporate Governance Terhadap Ketepatan Waktu Penyampaian Laporan Keuangan Perusahaan," Media Ris. Akunt., vol. 3, no. 2, pp. 43-65, 2017.

[2] W. Salipadang, R. Jao, and Beauty, "Pengaruh Mekanisme Good Corporate Governance terhadap Ketepatan Waktu Penyampaian Laporan Keuangan dan Dampaknya terhadap Return Saham,” Din. Akuntansi, Keuang. dan Perbank., vol. 6, no. 1, pp. 83-101, 2017.

[3] K. W. S. Saputra and I. W. Ramantha, "Pengaruh Profitabilitas Dan Ukuran Perusahaan Terhadap Ketepatan Waktu Pelaporan Keuangan Dengan Opini Audit Sebagai Pemoderasi," EJ. Akunt. Univ. Udayana, vol. 20, pp. 1592-1620, 2017.

[4] E. Juniati, A. H. MS, and A. A. A, "Analisis Faktor Yang Mempengaruhi Keterlambatan Penyampaian Laporan Keuangan Pada Perusahaan Pertambangan Yang Terdaftar Di BEI Tahun 2011-2013," JOM Fekon, vol. 3, no. 1, pp. 2414-2428, 2016.

[5] Pujiatmi and K. Ismawati, "Faktor yang Mempengaruhi Ketepatan Waktu Pelaporan Keuangan," Ekon. Bisnis dan Kewirausahaan, vol. 7, no. 1, pp. 43-76, 2018.

[6] C. Dodge, "Compliance Theory of Organizations," Springer Int. Publ., pp. 1-5, 2016.

[7] R. Januar and D. W. Handayani, "Pengaruh Ekstrinsik Reward dan Intrinsik Reward Terhadap Employee Performance: Telaah Pada PT. XYZ," Ultim. Manag., vol. 7, no. 1, pp. 25-38, 2015.

[8] F. M. Alshrife, I. Subekti, and Y. Widya, "The Effect Of Audit Committee Characteristics On Timeliness Of Financial Reporting By Using Auditor Quality As The Moderating Variable (An Empirical Study From Indonesian Manufacturing Companies),” Int. J. Account. Bus. Soc., vol. 24, no. 1, pp. 67-80, 2016.

[9] I. P. S. Sanjaya, "The Influence of Audit Committee to Earnings Management," J. Akunt. dan Investasi, vol. 7, no. 1, pp. 97-112, 2006.

[10] N. Soewarno, "The Effect of Good Corporate Governance Mechanism and Corporate Social Responsibility on Financial Performance with Earnings Mnagement as Mediating Variable," Asian J. Account. Res., vol. 3, no. 1, pp. 41-60, 2018.

[11] Suryato and D. R Meisa, "Good Corporate Governance, Capital Structure, and Firm's Values: Empirical Studies Food and Beverage Companies in Indonesia," Eur. J. Accounting, Audit. Financ. Res., vol. 4, no. 11, pp. 35-49, 2016.

[12] A. A. Dufrisella and E. S. Utami, "Pengaruh Good Corporate Governance terhadap Ketepatan Waktu Penyampaian Laporan Keuangan ( Studi Kasus Pada Perusahaan Manufaktur Di BEI )," $J R A M B$, vol. 6, no. 1, pp. 50-64, 2020.

[13] R. Mardyana, "Effect Of Good Corporate Governance, Financial Distress, And Financial Performance On Timeliness Of Financial Statements Reporting," J. Ilm. Mhs. FEB Univ. Brawijaya, vol. 3, no. 1, pp. 1-25, 2014.

[14] V. A. Tandean and Winnie, "The Effect of Good Corporate Governance on Tax Avoidance," Asian J. Account. Res., vol. 1, no. 1, pp. 28-38, 2016.

[15] H. W. Akani and R. L. T. Obiosa, "Effects of Financial Innovations on the Profitability of Deposit Money Banks in Nigeria," Eur. J. Accounting, Audit. Financ. Res., vol. 8, no. 1, pp. 52-73, 2020

[16] U. T. Agburuga and E. A. L. Ibanichuka, "Managerial and Controlling Ownership , Profitability , Firm Size and Financial Leverage in Nigeria," Int. J. Bus. Manag. Rev., vol. 4, no. 9, pp. 4357, 2016.

[17] L. Fujianti, "Analysis Market Reaction on Timeliness Reporting: Study on Indonesia Stock Exchange," Int. J. Bus. Manag. Invent., vol. 5, no. 3, pp. 1-10, 2016.

[18] M. Rivandi and M. M. Gea, "Pengaruh Mekanisme Corporate Governance Terhadap Ketepatan Waktu Pelaporan Keuangan ( Studi empiris Pada Perusahaan Perbankan Milik Pemerintah Pusat )," J. Akunt. dan Pajak, vol. 19, no. 01, pp. 1-9, 2018.

[19] I. B. K. Y. Mahendra and I. N. W. A. Putra, "Pengaruh Komisaris Independen, Kepemilikan Institusional, Profitabilitas, Likuiditas, Dan Ukuran Perusahaan Terhadap Ketepatwaktuan Publikasi Laporan Keuangan Tahunan,” E-Jurnal Akunt., vol. 9, no. 1, pp. 304-324, 2014. 
[20] E. Surachyati, E. Abubakar, and M. Daulay, "Analysis of Factors That Affect the Timeliness of Submission of the Financial Statements on Transportation Companies in Indonesia Stock Exchange," Int. J. Res. Rev., vol. 6, no. January, pp. 190-201, 2019.

[21] A. A. P. G. B. A. Susandya, I. A. N. Yuliastuti, and G. B. B. Putra, "The Effect of Cooperative's Characteristic on Financial Reporting Timeliness," Sriwij. Int. J. Dyn. Econ. Bus., vol. 2, no. 4, pp. 269-292, 2018. 